\title{
RESPONSE OF BROILER CHICKS TO DIETS WITH BAMBARANUT (VOANDZEIA SUBTERRANEA) AS A PROTEIN SOURCE
}

\author{
RÉPONSE DES POULETS DE CHAIR A LES RÉGIMES AVEC BAMBARANUT \\ (VOANDZEIA SUBTERRANEA) COMME SOURCE DE PROTÉINES
}

Nwaigwe, C.O. ${ }^{1 *}$, Akwuobu, C.A. ${ }^{2}$ and Kamalu, T.N. ${ }^{1}$

${ }^{1}$ Department of Animal Health and Production. University of Nigeria. Nsukka. Nigeria.

${ }^{2}$ College of Veterinary Medicine. University of Agriculture. Makurdi. Nigeria.

*Correspondence: Box 3298. University of Nigeria. Nsukka. docnwaigwe@yahoo.com

\section{AdDITIONAL KEYWORDS \\ Feed conversion. Weight gain. Digestibility.}

\section{SUMMARY}

The effects of raw and toasted bambaranut as a protein source for broiler chicks were investigated using 45 broiler chicks, randomly divided into three groups of 15 birds each. The test diets were formulated such that bambaranut constituted $25 \%$ of the diets. Treatment 1 (control) contained no bambaranut, treatment 2 contained raw bambaranut and treatment 3 toasted bambaranut.

The study lasted for 6 weeks during which weight gain and feed consumption were measured. The performance of the various groups was evaluated using weight gain, feed conversion ratio and cost per $\mathrm{kg}$ weight gain. At slaughter, various internal organs were excised, evaluated for gross lesions and weighed. The results of the study showed that the control group had superior feed conversion ratio and weight gain, while the raw bambaranut group was superior to the toasted bambaranut group. Cost per kg weight gain was higher in the toasted bambaranut groups. There were neither statistically significant differences $(p>0.05)$ in the organ weights nor observable abdominal fat and gross pathology of the internal organs.

\section{RÉSUMÉ}

Les effets de la noix de bambara cru et grillé comme source de protéine pour les poulets de chair a été examinée en utilisant 45 broilers qui ont été divisés au hasard en trois groupes de 15 oiseaux. Les régimes de test ont été formulés tel

Recibido: 4-1-07. Aceptado: 8-2-07.

\section{MOTS CLÉS}

Conversion d'aliment. Gain de poids. Digestibilité.

ce la noix de bambara a constitué $25 \%$ du total. Le traitement 1 (contrôle) sans noix de bambara, le traitement 2 avec noix de bambara cru et le traitement 3 avec noix bambara réchauffée.

L'étude a duré 6 semaines pendant lesquelles le gain du poids et la consommation de l'aliment ont été mesurées. Les résultats obtenus par des divers groupes ont été évalués en utilisant les gains du poids, la conversion d'aliment, et le coût par kg gaigné. Pendant l'abattage, les divers organes internes ont été excisés et évalués pour les grands lésions et pesés. Les résultats de l'étude ont montré que le groupe de contrôle avait le plus haut ratio de conversion d'aliment et gain du poids, pendant que le groupe de la noix de bambara cru était supérieur au groupe de la noix de bambara réchauffée. Le coût par kg gaigné était plus haut dans les groupes de la noix de bambara réchauffée. II n'avait pas des différences statistiques ( $p>0.05$ ) pour les poids d'organes ni pour le tissu adipeux abdominal observable et la grand pathologie dans les organes internes.

\section{INTRODUCTION}

Feed cost has constantly been reported to impede progress of poultry production world-wide. It has been estimated to account for over $50 \%$ the cost of raising commercial poultry in Nigeria (Uko and Kamalu, 2003). Part of this problem has been the unavailability and high cost of 
protein supplements (Obioha, 1992).

The major locally available plant protein sources commonly used in poultry feed production are soybeans meal and groundnut cake. Soya bean meal has been reported to be scarce and expensive while groundnut cake has been reported to have aflatoxins (McDonald et al., 1998). It is therefore necessary to search for cheaper and locally available replacement alternatives such as bambaranut. The dried seeds of bambaranut contain $14-24 \%$ crude protein, $6.5 \%$ either extract and low fibre; the protein is of high biological value with fair amount of sulphurbased amino acids (Ensminger et al., 1990). It has high amount of lysine and methionine (Poulter, 1981), as well as protein of high biological value (FAO, 1982). The study reported herein investigated the use of bambaranut as a protein source in broiler diets.

\section{MATERIALSAND METHODS}

Forty-five day-old broiler chicks obtained from a local hatchery were used for the experiment. On arrival, they were distributed at random to three equal groups, which were randomly assigned into three different experimental units which had been cleaned and disinfected previously. They were placed on anti-stress chemotherapy which lasted for five days. The birds were adequately vaccinated, and coccidiostat was also given to prevent coccidiosis. The birds were brooded in the poultry house of the Veterinary farm, University of Nigeria, Nsukka, and the brooding lasted for 5 weeks after which the brooding pens were converted to broiler finisher units.

Three experimental diets (T1, T2 and T3), containing 22\% protein respectively (table I) were formulated such that bambaranut, toasted or raw, replaced $25 \%$ of soya bean meal on a weight for weight basis. T1 was control diet, T2 contained raw bambaranut and T3 contained toasted bambaranut. The diets were randomly allotted to the
Table I. Composition of experimental diets (\% of DM). (Composition de régimes expérimentaux, \% du MS).

\begin{tabular}{lccc}
\hline & \multicolumn{3}{c}{ Treatments } \\
Ingredients (\%) & T1 & T2 & T3 \\
\hline Maize & 62.00 & 45.00 & 45.00 \\
Soya bean meal & 23.00 & 15.00 & 15.00 \\
Raw BNM & - & 25.00 & - \\
Toasted BNM & - & - & 25.00 \\
Fish meal & 10.00 & 10.00 & 10.00 \\
Palm oil & 1.80 & 1.80 & 1.80 \\
Bone meal & 2.00 & 2.00 & 2.00 \\
Vit./Mineral premix & 0.50 & 0.50 & 0.50 \\
Salt & 0.50 & 0.50 & 0.50 \\
Methionine & 0.20 & 0.20 & 0.20 \\
& & & \\
Total & 100.00 & 100.00 & 100.00 \\
& & & \\
Calculated composition $(\%):$ & & \\
& & & \\
Crude protein & 22.36 & 22.23 & 22.23 \\
ME Kcal/kg & 3265.52 & 3213.35 & 3213.35 \\
Ether extract & 4.74 & 5.09 & 5.41 \\
Crude fibre & 2.84 & 5.36 & 5.39 \\
Calcium & 1.40 & 2.77 & 2.77 \\
Phosphorus & 0.79 & 0.73 & 0.73 \\
Lysine & 1.25 & 2.58 & 2.58 \\
Methionine & 0.62 & 0.80 & 0.80 \\
& & & \\
& & &
\end{tabular}

Composition of bambaranut meal (decorticated).

\begin{tabular}{lccccc}
\multicolumn{2}{c}{$\% \mathrm{DM}$} & \multicolumn{2}{c}{$\mathrm{mg} / 100 \mathrm{~g}$} & \multicolumn{2}{c}{$\%$} \\
CP & 20.6 & Fe & 4 & Arg & 1.22 \\
CF & 4.0 & VitA & 30 & His & 0.58 \\
EE & 6.3 & VitC & 1.0 & Lys. & 1.24 \\
Ash & 3.0 & & & Leu & 1.54 \\
NFE & 54.9 & & & Met & 0.35 \\
Ca & 0.11 & & & Cys & 0.56 \\
P & 0.08 & & & Tryp & - \\
& & & & Val. & 1.03 \\
\hline
\end{tabular}

Source: Olomu, 1995.

T1: Treatment 1 (control diet);

T2: Treatment 2- Raw bambaranut;

T3: Treatment 3- Toasted bambaranut; 
Table II. Effects of the dietary treatments on weight gain, feed conversion ratio, digestibility and cost of production of the diets. (Les effets de traitements alimentaires sur le gain de poids, le rapport conversionnel, la digestibilité et le coût de la production alimentaires).

\begin{tabular}{lccc}
\hline & \multicolumn{3}{c}{ Treatments } \\
Parameters & T1 & T2 & T3 \\
\hline Mean weight gain $(\mathrm{kg})( \pm \mathrm{SEM})$ & $2.15 \pm 0.044^{\mathrm{a}}$ & $2.03 \pm 0.035^{\mathrm{b}}$ & $1.97 \pm 0.029^{\mathrm{b}}$ \\
Feed conversion ratio (feed/gain) & $1.72 \pm 0.36$ & $1.80 \pm 0.55$ & $1.90 \pm 0.43$ \\
Cost per kg weight gain $(\mathrm{N})$ & $135.44 \pm 0.66$ & $135.90 \pm 0.45$ & $148.22 \pm 0.38$ \\
\hline
\end{tabular}

Means $( \pm$ SEM) with different superscripts across the row are significantly different $(p<0.05)$.

three units. Feed and water were provided ad libitum for a feeding period of 6 weeks, during which data were collected on weight gain, feed consumption and feed conversion ratio. The composition of the formulated diets were subsequently determined (A.O.A.C., 1990).

At the end of the study, cost per kg weight gain was calculated and two birds from each group were slaughtered and their

Table III. Organ weights, gross pathological lesions and observable abdominal fat in the organs of various treatment groups. (Poids des organes, les lésions pathologiques bruts et le tissu adipeux abdominal observable dans les organes de divers groupes de traitement).

\begin{tabular}{|c|c|c|c|}
\hline \multirow[t]{2}{*}{ Organs } & \multicolumn{3}{|c|}{ Treatments (\% body weight \pm SEM) } \\
\hline & $\mathrm{T} 1$ & $\mathrm{~T} 2$ & T3 \\
\hline Gizzard & $2.80 \pm 0.30$ & $2.80 \pm 0.30$ & $2.21 \pm 0.007$ \\
\hline Liver & $1.65 \pm 0.05$ & $1.85 \pm 0.16$ & $1.53 \pm 0.12$ \\
\hline Spleen & $0.16 \pm 0.02$ & $0.19 \pm 0.02$ & $0.14 \pm 0.04$ \\
\hline Pancreas & $0.19 \pm 0.01$ & $0.25 \pm 0.02$ & $0.20 \pm 0.04$ \\
\hline Intestine & $2.88 \pm 0.30$ & $3.93 \pm 0.08$ & $3.36 \pm 0.56$ \\
\hline Heart & $0.46 \pm 0.02$ & $0.49 \pm 0.04$ & $0.48 \pm 0.03$ \\
\hline Lungs & $0.44 \pm 0.02$ & $0.49 \pm 0.04$ & $0.46 \pm 0.01$ \\
\hline Gall bladder & $0.19 \pm 0.07$ & $0.14 \pm 0.01$ & $0.15 \pm 0.03$ \\
\hline Proventriculus & s $0.31 \pm 0.05$ & $0.46 \pm 0.01$ & $0.38 \pm 0.05$ \\
\hline Kidney & $0.53 \pm 0.03$ & $0.61 \pm 0.30$ & $0.47 \pm 0.08$ \\
\hline Abdominal fa & low & low & low \\
\hline
\end{tabular}

internal organs and abdominal fats excised, weighed and evaluated for gross pathological lesions.

Data were subjected to analysis of variance (ANOVA) as outlined by Steel and Torrie (1980), while the means were separated using the method of Duncan (1955).

\section{RESULTSANDDISCUSSION}

Data on weight gain showed that the mean of the control group differed significantly $(p<0.05)$ from that of the raw and toasted bambaranut-based groups, whereas there was no significant difference in the means of the raw and toasted bambaranutbased groups $(p>0.05)$. Feed conversion ratio was also not statistically significant between groups.

Consequently, results on table III revealed that the percentage body weight of the internal organs did not differ significantly ( $p>0.05)$ between the treatment groups. This indicated that the treatments had no observable gross pathological effects regarding an abnormal increase in the weight or size of the various internal organs measured.

\section{CONCLUSION}

In conclusion, the results of this study suggest that bambaranut can partially replace soya bean meal in broiler diets, and the $25 \%$ dietary level of raw bambaranut did 
not provide enough quantity of antinutritional factors to elicit growth retar-

\section{REFERENCES}

A.O.A.C. 1990. Association of Official Analytical Chemists. Official method of analysis. $15^{\text {th }} \mathrm{Ed}$. Washington D.C.

Duncan, D.B. 1955. New multiple range test. Biometrics, 11: 1-2.

Ensminger, M.E., Oldfield, J.E. and Heinemann, W.W. 1990. Feeds and nutrition. The Ensminger Publishing C.O. Clovis, California. U.S.A.

FAO. (Food and Agricultural Organization). 1982. Legumes in human nutrition. FAO Food and Nuturition Paper $N^{\circ} 21$. Food and Agricultural Organization. Rome. Italy.

McDonald, P., Edwards, R.A. and Greenhalgh, J.F.D. 1998. Animal nutrition. $5^{\text {th }}$ Ed. pp. 232-235.

Obioha, F.C. 1992. A guide to poultry production in the tropics. Acena Publishers. Enugu. Nigeria. pp. 30-42. dation or any observable toxic effects in the experimental diets.

Olomu, J.M. 1995. Monogastric Animal Nutrition and Practice. Jacham Publishers. Ibadan. Nigeria.

Poulter, N.H. 1981. Properties of some protein fration from bambara groundnut (Vaodzeia subteranea (L) Thouars). J. Sci. Food Agric., 32: 44-50.

Steel, R.G.D. and Torrie, J.H. 1980. Principles and procedures of statistics: A biometric approach. $2^{\text {nd }}$ Ed. McGraw-Hall Book Co. Inc. New York. U.S.A.

Uko, J.O. and Kamalu, T.N. 2003. Studies on feeding value of neem seed kernel (Azadirachta Indica A. Juss) in Poultry meat production. Ph. D. Thesis. Department of Veterinary Physiology/ Pharmacology. University of Nigeria. Nsukka. Nigeria.

Archivos de zootecnia vol. 59, núm. 225, p. 144. 